Dipartimento di Scienze Statistiche

Sezione di Statistica Economica ed Econometria

Syed Basher Stefano Fachin

\title{
Investigating Long-Run Demand for Broad Money in the Gulf Arab Countries
}

DSS Empirical Economics and Econometrics

Working Papers Series 


\section{DSS Empirical Economics and Econometrics Working Papers Series}

ISSN 2279-7491

2011/1 Massimo Franchi, Paolo Paruolo "Normal forms of regular matrix polynomials via local rank factorization"

$2011 / 2$ Francesca Di lorio, Stefano Fachin "A Sieve Bootstrap range test for poolability in dependent cointegrated panels"

2011/3 Maria Grazia Pittau, Shlomo Yitzhaki, Roberto Zelli "The makeup of a regression coefficient: An application to gender"

2011/4 Søren Johansen "The analysis of nonstationary time series using regression, correlation and cointegration - with an application to annual mean temperature and sea level"

2011/5 Mario Forni, Marc Hallin, Marco Lippi, Paolo Zaffaroni "OneSided Representations of Generalized Dynamic Factor Models"

2012/1 Marco Avarucci, Eric Beutner, Paolo Zaffaroni "On moment conditions for Quasi-Maximum Likelihood estimation of multivariate GARCH models"

2012/2 Francesca Di lorio, Stefano Fachin "Savings and Investments in the OECD: a panel cointegration study with a new bootstrap test"

2012/3 Francesco Nucci, Alberto Pozzolo "Exchange rate, external orientation of firms and wage adjustment"

2012/4 Massimo Franchi, Paolo Paruolo "On ABCs (and Ds) of VAR representations of DSGE models"

2012/5 Massimo Franchi, Anna Vidotto "A simple check for VAR representations of DSGE models"

Dipartimento di Scienze Statistiche Sezione di Statistica Economica ed Econometria "Sapienza" Università di Roma P.le A. Moro 5 - 00185 Roma - Italia http://www.dss.uniromal it 


\title{
Investigating Long-Run Demand for Broad Money in the Gulf Arab Countries*
}

\author{
Syed Abul Basher ${ }^{\dagger} \quad$ Stefano Fachin ${ }^{\ddagger}$
}

December 9, 2012

\begin{abstract}
We estimate the long-run demand for broad money at the Gulf Cooperation Council area level (Bahrain, Kuwait, Oman, Qatar, Saudi Arabia and the United Arab Emirates (UAE)) and at single country level over the 1980-2009 period. Applying time series and panel econometric tests, we first document the existence of long-run equilibrium relationship for money demand - both nationally and regionally. The estimated income- and interest elasticities in Qatar, Saudi Arabia and the UAE provide a validation for the Baumol-Tobin version of the inventory analysis of the transactions demand for money; while income elasticities in the other GCC economies reflect portfolio demand more strongly than transaction demand with a generally lower interest rate (semi-)elasticities. We discuss how the movements in income velocity can reconcile the varying elasticities documented across the six countries. The different pooled estimators of the regional money demand produce estimated income elasticities in the neighborhood of unity, while interest rate elasticities tend to be smaller than -0.2.
\end{abstract}

JEL Codes: C23, E41, E52.

Keywords: Money demand; Endogenous money; Gulf monetary union; Panel cointegration; Poolabiilty.

\footnotetext{
${ }^{*}$ We are grateful to Elsayed Elsamadisy for stimulating discussions and helpful comments, to Khalid Alkhater and Markus Eberhardt for useful conversation, to Megan Foster for help with proofreading and to the participants at the 2012 Italian Statistical Society conference for comments and suggestions. The views expressed here are those of the authors and do not necessarily reflect the official view of the Qatar Central Bank. The errors that remain are solely ours.

${ }^{\dagger}$ Corresponding author: Department of Research and Monetary Policy, Qatar Central Bank, P.O. Box 1234, Doha, Qatar. Tel.: +(974)44456490; Fax: +(974)44416771. E-mail: bashers@qcb.gov.qa

${ }_{\ddagger}^{\ddagger}$ Dip. di Scienze Statistiche, University of Rome "La Sapienza", P. le A. Moro 5, 00185 Roma, Italy. E-mail: s.fachin@caspur.it
} 


\section{Introduction}

To date, only a small number of studies have attempted a systematic analysis of the longrun money demand functions in the Gulf Cooperation Council (GCC) countries, which include Bahrain, Kuwait, Oman, Qatar, Saudi Arabia and the United Arab Emirates (UAE). Part of the reason for the lack of interest in the demand for money is the difficulty in obtaining consistent time series data across the six countries. Past estimation of money demand functions, partially surveyed in Tahir (1995), was confined to country-specific studies predominantly covering Kuwait and Saudi Arabia. A consensus that emerged from the early studies is that both income and foreign interest rates are the key determinants of real money balances in the Gulf Arab countries. Recently, interest has been shifted to understand the long-run equilibrium relationship of money demand at the GCC-wide level using non-stationary panel data methods cf. Harb (2004) and Lee, Chang and Chen (2008).

In this paper, we examine the time series properties of the long-run demand for broad money in the GCC countries using annual data over the 1980-2009 period. To the best of our knowledge, this is the first paper to offer a systematic assessment of the long-run money demand function for individual member countries and for the GCC area as a whole. Particularly for central banks in the GCC region, a clear understanding of the demand for money is important for at least two reasons. First, money supply is determined endogenously, where the primary function of the GCC central banks is to manage liquidity in the banking system. The endogeneity of money stems from two important factors. On the one hand, the long-standing de facto peg of the GCC countries to the United State (US) dollar implies that, to some extent, changes in the domestic money supply are due to changes in interest rates in the anchoring country (i.e., the US). Admittedly, some amount of money supply is imported through the interest rate parity implied by the exchange rate parity. This is the outcome of the well-known "impossible trinity", whereby it is impossible for a country to maintain an independent monetary policy under a fixed exchange rate with free capital movements. ${ }^{1}$ On the other hand, to a considerable extent, the pace of monetary expansion is determined by the pace of a government's domestic expenditure, which is the main engine of economic growth in the (private) non-oil sector. In financing public spending programs, the government spends a portion of its oil revenues, causing the inflow of foreign exchange from oil exports to translated into increases in domestic liquidity

\footnotetext{
${ }^{1}$ Rodríguez and Rowe (2007) showed that changes in the US monetary instrument (the US federal funds rate or the US money supply) have real effects in Hong Kong, where the currency is pegged to the US dollar.
} 
in the banking system. This is the so-called "budgetary transmission channel" through which oil income is channeled to the economic through government spending, see Zaidi (1990). Together, these two forces determine (or create) a large portion of money supply endogenously, ${ }^{2}$ while the central bank mostly functions as a manager of liquidity in the financial system. ${ }^{3}$

The findings of some recent contributions validate the claims made above. Tas and Togay (2012) offer econometric tests for alternative views related to the theory of endogenous money as developed by the Post-Keynesian school. Their results overwhelmingly support the 'structural' and 'liquidity preference' views of endogenous money supply in all GCC countries, while the accommodationist view could not be validated by the GCC data. ${ }^{4}$ Employing a panel vector autoregression (VAR) model for the GCC, Espinoza and Prasad (2012) found a strong and statistically significant impact of U.S. monetary policy on broad money and other macroeconomic indicators in the GCC region. Likewise, Bova (forthcoming) found that the GCC's interest rates are all cointegrated with the US interest rate, with the long-run coefficient being very close to one, thus providing additional validation of the interest parity condition.

The second reason for studying the demand for money is that for many years, the GCC countries have been contemplating forming a monetary union. Although the GCC countries have already fulfilled many of the preconditions for a currency union, ${ }^{5}$ there have also been some unanticipated setbacks to achieving the monetary union (Khan, 2009). Nevertheless, at the time of writing, the commitment to continue with the GCC monetary union project is still deep and ongoing despite the recent spate of skepticism over the wisdom of continuing with this monetary union.

The significance of the money demand function for the common central bank in a monetary union cannot be overemphasized. In particular, knowledge of the behavior of the demand for money in each member state is a crucial prerequisite for the conduct of monetary policy. This can

\footnotetext{
${ }^{2}$ Other exogenous factors that can lead to domestic money creation or destruction are short-term speculative flows in the stock market and the real estate sector. Furthermore, the case of money laundering as a contributing factor cannot be ruled out.

${ }^{3}$ Nevertheless, the ability to influence money supply varies across the six Gulf countries. For example, the bulk of Saudi Arabia's oil revenues which are held as reserves with the Saudi Arabia Monetary Agency (SAMA), Saudi Arabia's central bank, allow SAMA to impact domestic money growth through buying and selling US dollars in the banking system. Further, some Gulf central banks are better equipped with instruments of monetary sterilization and other prudential tools to manage liquidity.

${ }^{4}$ Briefly, under the accommodationist view, the money supply is demand-determined (i.e., bank loans) and the central bank provides reserves and currency on demand. The structuralist view argues that the central bank keeps some control over the supply of reserves, while the liquidity preference view implies a bi-directional causality between bank loans and money supply. See Tas and Togay (2012) for further discussion.

${ }^{5}$ There is a burgeoning branch of literature on the feasibility and progress of the GCC monetary union - see, among many others, Buiter (2008) and AlKholifey and Alreshan (2010).
} 
be examined by testing cointegrating relationships between money demand and macroeconomic variables like income and interest rates for each of the member states or for the panel as a whole. Further, the common monetary operation implies the homogeneity of income and interest rate coefficients across all members in the monetary union. Both of these issues are central to our empirical investigation and these are addressed using recently developed panel tests that are particularly suitable for small panel such as the GCC.

A number of earlier studies based on (non-stationary) panel methods have examined the long-run demand for money in the GCC countries. Harb (2004) modeled M1 money demand for GCC countries from 1979-2000 and found cointegration between money and non-oil GDP when the trend is not included. However, using different serial correlation adjustment methods, Westerlund and Basher (2008) could not reject the null hypothesis of no cointegration using the same data as Harb. Further, Harb's use of M1 money is problematic, as it does not accurately reflect the private sector's demand for money in GCC countries (further details provided below). Lee et al. (2008) also utilized Harb's dataset but employed likelihood-based cointegration tests (as opposed to the residual-based cointegration tests employed by Harb) and found evidence of two cointegrating relationships in the money demand equations for GCC countries. Although no details of the multiple cointegration relationships were provided, a possible interpretation of their results is the bi-directional causation between money and non-oil GDP documented for the GCC countries (cf. Basher and Elsamadisy, 2012).

Our paper differs from the earlier literature in two key aspects. First, we estimate the money demand function for the individual GCC countries using annual data over the 1980-2009 period, thus covering the recent expansion of GCC economies and the fallout of the financial crisis two important economic events of the past decade. Second, after testing the coefficients of these individual functions for homogeneity, we estimate the regional money demand function. This can be a key policy tool in view of the planned monetary union. The structure of this paper is as follows: Section 2 discusses the specifications of the model and the choice of variables; Section 3 presents and analyzes the empirical results; Section 4 concludes the paper.

\section{Model Specifications}

Since our goal is to find the existence of long-run equilibrium relationships for money demand in each of the GCC member countries, we consider two alternative models of the money demand 
function. These are:

$$
\begin{aligned}
& \ln \left(\frac{M_{t}}{P_{t}}\right)=\text { constant }+\beta \ln \mathrm{Y}_{\mathrm{t}}+\gamma \mathrm{R}_{\mathrm{t}}+\epsilon_{\mathrm{t}}, \\
& \ln \left(\frac{M_{t}}{P_{t}}\right)=\text { constant }+\beta \ln \mathrm{Y}_{\mathrm{t}}+\theta \ln \mathrm{R}_{\mathrm{t}}+\epsilon_{\mathrm{t}},
\end{aligned}
$$

where $M$ denotes the stock of nominal money, $P$ is the consumer price index used to convert nominal balances into real balances, $Y$ is the scale variable, $R$ is the nominal interest rate (opportunity cost) variable and $\epsilon$ is an error term. Equation (1) is the standard semi-log specification, where $\beta$ and $\gamma$ denote income elasticity and interest semi-elasticity, respectively. Equation (2) characterizes the log-log specification of the inventory-theoretic approach pioneered by Baumol (1952) and Tobin (1956), where $\theta$ is interpreted as interest elasticity. The main motivation for exploring the log-log specification is that semi-elasticity with respect to the interest rate is highly sensitive to slight changes in interest rates during the low-interest rate regime, a phenomenon that cannot be ruled out in our data (Fig. 3 and Table 2). Hence, Equation (2) includes the 'liquidity trap' phenomenon because the demand for money increases to infinity as the interest rate approaches zero. ${ }^{6}$

The first problem in the empirical estimation of models (1) and (2) is the selection of a relevant measure of money. The monetary aggregate considered here is broad money (M2) for the following reasons. First, unlike financially developed economies where a narrow definition of money (M1) tends to be more responsive to open market and interest rate policies, in the GCC countries, the M1 money primarily reflects the 'supply side' of monetary aggregation due to the endogeneity of money creation discussed in the introduction. Second, the predominance of borrowing from the banks as the major source of financing domestic private economic activities indicates that availability rather than the cost of credit is more likely to influence money demand by the private sector. ${ }^{7}$ Further, as suggested by Crockett and Evans (1980), in many developing countries including the GCC, the available policy instruments such as prudential measures are used to affect the volume of credit extended by the banking system, thereby allowing monetary authorities to exert a greater control over the total liabilities of the banking system (M2) than a particular component. ${ }^{8}$ The use of M2 money can also be justified on the grounds of the

\footnotetext{
${ }^{6}$ See Goldfeld and Sichel (1990) for a discussion of the relationships among the functional form of money demand, the existence of the liquidity trap and the effectiveness of monetary policy.

${ }^{7}$ According to the International Monetary Fund (IMF) (2009), bank assets and equities account for $94.4 \%$ of finance in the Middle East countries.

${ }^{8}$ National credit policies are a powerful economic/politcal tool in GCC countries. Besides stimulating invest-
} 
increasing deregulation of the GCC financial system, with financial institutions now offering a variety of interest-bearing checking accounts and checkable savings accounts.

The role of the scale variable in the money demand function is to measure transactions relating to economic activity. The commonly used indicator of total gross domestic product (GDP) to proxy the scale variable is challenging, since oil accounts for as much as half of the GCC's aggregate output. As crude oil production is not economically integrated with the rest of the economy, decisions on the volume of oil production neither affect nor are affected by monetary creation, and there is no direct effect on the liquidity of the private sector (Crockett and Evans, 1980; Fadil, 1985). In recognition of these facts, the majority of the earlier empirical studies have considered using non-oil GDP as a proxy for the volume of transactions in the domestic economy. As nearly all private activities rest on the non-oil sector, it is more likely that demand for money in GCC countries is influenced by non-oil GDP, which we also consider here as a proxy for the scale variable.

Regarding the choice of the opportunity cost variable, two alternatives (among other variables) have emerged in the literature. Given the openness of the GCC economies, it is likely that the holding of money balances is influenced by movements in the interest rate. However, the available time series of country-specific interest rates are too short to permit a high degree of confidence in the resulting estimates. To circumvent this problem, some authors ${ }^{9}$ have employed foreign interest rates on the basis of a presumed 'interest rate parity' between GCC and foreign countries (mostly notably, the US). ${ }^{10}$ Although correlation coefficients have to be used with caution in view of possibile non-stationarity, Sbeiti and Haddad (2011) report values so high that close links appear evident (for instance, the correlation between domestic short-term interest rates and the US Treasury bill rate is about 94\%, 97\%, 99\%, and $70 \%$ for Kuwait, Saudi Arabia, Bahrain, and Oman, respectively).

Consequently, we have employed the 3-month US Treasury bill rate as our main proxy for the opportunity cost variables. For sake of comparison, we have also considered alternative ment in certain sectors, governments use the credit tool to distribute the proceeds from oil wealth to its citizens. The recent Arab uprising has prompted some GCC authorities to rely exclusively on the credit channel to provide soft long-term funding (including housing) to their nationals.

${ }^{9}$ See Darrat (1986), Darrat and Al-Sowaidi (2009), and Sbeiti and Haddad (2011).

${ }^{10}$ Although, in the recent decade (2001-2010), the empirical relationships between the US and the GCC interest rates has been different compared with the findings of the long-run relationships. For instance, over the 2004-2011 period, Espinoza and Prasad (2012) reported evidence of low pass-through to GCC interest rates from the US rate. Over the same time period, Elsamadisy, Alkhater and Basher (2012) rejected the uncovered interest rate parity between Qatar and the US. However, since we are interested in analyzing the long-term relationships, we do not believe that these short-term results present a challenge to our analysis. 
interest rates such the London interbank offered rate (LIBOR), both the United Kingdom (UK) and the US version, and the 10-year yield on US government bonds. Given that the foreign interest rate is identical across all units, it can be interpreted as an observed common factor, which, in turn, induces dependence across the cross-section in the panel.

The expected rate of inflation is often considered as an alternative measure of the opportunity cost of holding money in developing countries. This is due to the underdevelopedness of domestic financial markets and/or government controls over market interest rates that is generally observed in developing countries. As argued by Darrat (1986), the main objection to the inclusion of expected inflation in the money function entails a significant misspecification, as it a priori assumes a closed economy. Given the openness (and the free capital movements) of the GCC economies, the international opportunity costs of holding money can be as important as the domestic counterpart. This argument appears especially relevant for GCC countries where the possibilities of holding financial assets outside the banking system are limited. For both theoretical and practical reasons, therefore, it seems appropriate to estimate the money demand functions using interest rates as the opportunity cost of holding money.

\section{Empirical Results}

As can be appreciated from Fig. 1 and Table 1, over the period examined, M2 grew very fast in real terms in all GCC economies. In 2009, the M2 real stock in Oman and Qatar was about 13 times the 1980 level; in Bahrain, Saudi Arabia and the UAE, it was over eight times higher; three times higher in Kuwait; and about seven times higher in the GCC as a whole. In all cases except Oman, the fastest growth took place after 2000: in the GCC the average growth for 2000-2009 (10.9\%) has been considerably faster than that for the 1980s (6.9\%) and almost four times faster than that for the 1990s (3.0\%). Interestingly, the combination of strong growth in M2 money and the lower level of interest rates (Table 2) documented in the last decade supports the log-log specification in money demand discussed above.

Growth of non-oil GDP (Fig. 2 and Table 1), although somehow slower, has also been generally rather fast, with some exceptions in the mid-1980s when output actually fell in all countries due to the collapse in global oil prices. In this case as well, growth was strongest after 2000 (7.5\% per annum, more than twice as much as in the previous decade, $3.6 \%)$. On the average, the UAE showed the fastest growth; Saudi Arabia and Kuwait the slowest. In the 
Table 1: Real M2 and non-oil GDP growth in the GCC economies, 1980-2009

\begin{tabular}{cccccccc}
\hline \hline & Bahrain & Kuwait & Oman & Qatar & Saudi Arabia & UAE & GCC \\
\hline \multicolumn{7}{c}{ A. 1980-1989 } \\
M2 & 5.2 & 4.1 & 11.8 & 7.8 & 8.8 & 6.8 & 6.9 \\
$Y$ & 8.9 & 0.8 & 5.6 & 8.7 & 3.9 & 5.3 & 4.8 \\
\hline \multicolumn{7}{c}{ B. 1990-1999 } \\
M2 & 7.0 & -0.2 & 6.2 & 4.0 & 3.8 & 3.0 & 3.0 \\
$Y$ & 3.1 & 0.8 & 5.8 & 2.1 & 2.3 & 10.9 & 3.6 \\
\hline \multicolumn{7}{c}{ C. 2000-2009 } \\
M2 & 10.9 & 9.1 & 9.7 & 16.1 \\
$Y$ & 7.5 & 9.8 & 9.4 & 15.3 & 10.3 & 13.2 & 10.9 \\
\hline \multicolumn{7}{c}{ D. 1980-2009 } \\
M2 & 7.6 & 4.2 & 9.4 & 9.2 & 7.8 & 7.8 & 7.5 \\
$Y$ & 6.7 & 3.9 & 7.3 & 8.6 & 3.4 & 9.9 & 5.1 \\
\hline \hline
\end{tabular}

latter case, the 1991 Iraqi invasion had an obvious dramatic impact, with the 1991 value being only $60 \%$ of that of the previous year. On the other hand, Kuwait's real money balances do not seem to have been affected. This impression is confirmed by a search using the TRAMO procedure (Gómez and Maravall, 2001), ${ }^{11}$ which identifies 1991 as an additive outlier (AO) for non-oil GDP only. The explanation of this difference is very simple: money aggregates are end of period stocks, while GDP is a flow measure which reflects the entire year. ${ }^{12}$ Hence the Iraqi occupation, which ended in April 1991, affected GDP but not necessarily the path of the nominal money balances. From the modelling point of view, this implies that we should either treat the 1991 observation for Kuwait's non-oil GDP as a missing observation and replace it with some estimate, or use a suitable dummy. Maravall and Peña (1992) show the two approaches to be equivalent; our choice fell on the first option. We thus replaced the 1991 GDP observation with the ARIMA estimate offered by TRAMO, as currently used by many official statistical agencies (e.g., Eurostat) for the treatment of missing observations.

Finally, as is well-known, both short- and long-term interest rates (measured here by the

\footnotetext{
${ }^{11}$ TRAMO (Time Series Regression with ARIMA Noise, Missing Observations and Outliers) is a program for estimating and forecasting regression models with possibly non-stationary (ARIMA) errors and any sequence of missing values. A computer code implementing the program is available as a free download at http://www. bde.es.

${ }^{12}$ In fact, domestic liquidity was supported by the fractional withdrawal of Kuwait's external assets to financial reconstruction after the 1991 Gulf War. For instance, in late 1991, the government agreed to purchase US $\$ 20$ billion worth of domestic debt held by Kuwaiti nationals and businesses in exchange for bonds. See Metz (1993) for further discussion.
} 
3-month US Treasury bill rate, the UK and US LIBOR rates and the yield of 10-year US government bonds) followed markedly negative trends (see Fig. 3 and Table 2). On the other hand, inflation appears to be roughly stationary in all countries (see Fig. 4).

Table 2: Interest rates, 1980-2009

\begin{tabular}{lcccc}
\hline \hline & $1980-89$ & $1990-99$ & $2000-09$ & $1980-2009$ \\
\hline$r_{S}^{U S}$ & 8.8 & 4.9 & 2.8 & 5.5 \\
$r_{L}^{U S}$ & 10.6 & 6.7 & 4.5 & 7.2 \\
$r_{l i b}^{U S}$ & 10.5 & 5.5 & 3.3 & 6.4 \\
$r_{\text {lib }}^{U K}$ & 12.1 & 8.0 & 4.6 & 8.2 \\
\hline \hline$r_{S}^{U S}:$ US 3-month Treasury bill rate; \\
$r_{L}^{U S}:$ US 10-years Treasury bonds rate; \\
$r_{\text {lib }}^{U S}$ : US LIBOR rate; \\
$r_{\text {lib }}^{U K}:$ UK LIBOR rate. \\
Average rates $\times$ 100. Source: International Finan- \\
cial Statistics, International Monetary Fund.
\end{tabular}

Consistent with our expectations and a visual inspection of the plots, the ADF-GLS tests of Elliott, Rothenberg and Stock (1996) suggest non-stationarity for all variables except inflation rates, although non-oil GDP is borderline in Oman and the UAE (details in Table 3). Interestingly, the test for Kuwait non-oil GDP is not significantly affected by the bias against the null of a unit root which can be expected in presence of AOs (Franses and Haldrup, 1994). The presence of this bias can be appreciated by comparing the results of the series contaminated by the AO and the linearized series, in which the 1991 observation is replaced by the ARIMA estimate. Although the ADF-GLS statistics for both series are well in the non-rejection region, those of the contaminated series are larger in absolute value and hence are less favorable to non-stationarity.

We can now proceed to test for the existence of long-run money demand functions for each of the GCC countries and to estimate their parameters. On the basis of the unit root tests, we will not include inflation rates in our specifications. The cointegrating regressions are based on models (1) and (2) as discussed in the previous section. In view of the small sample size (30 observations), we are forced to apply parsimonious single equation methods. As an initial step, we therefore computed standard Engle-Granger 'no cointegration' tests. Given that we have to use proxy interest rates, we searched for the best results with short- and long-term US rates as well as the UK and US LIBOR interest rates, both in natural values and in logarithms. The final results, reported in Table 4, are mixed: the $p$-values of the Engle-Granger tests 
Table 3: ADF-GLS unit root tests

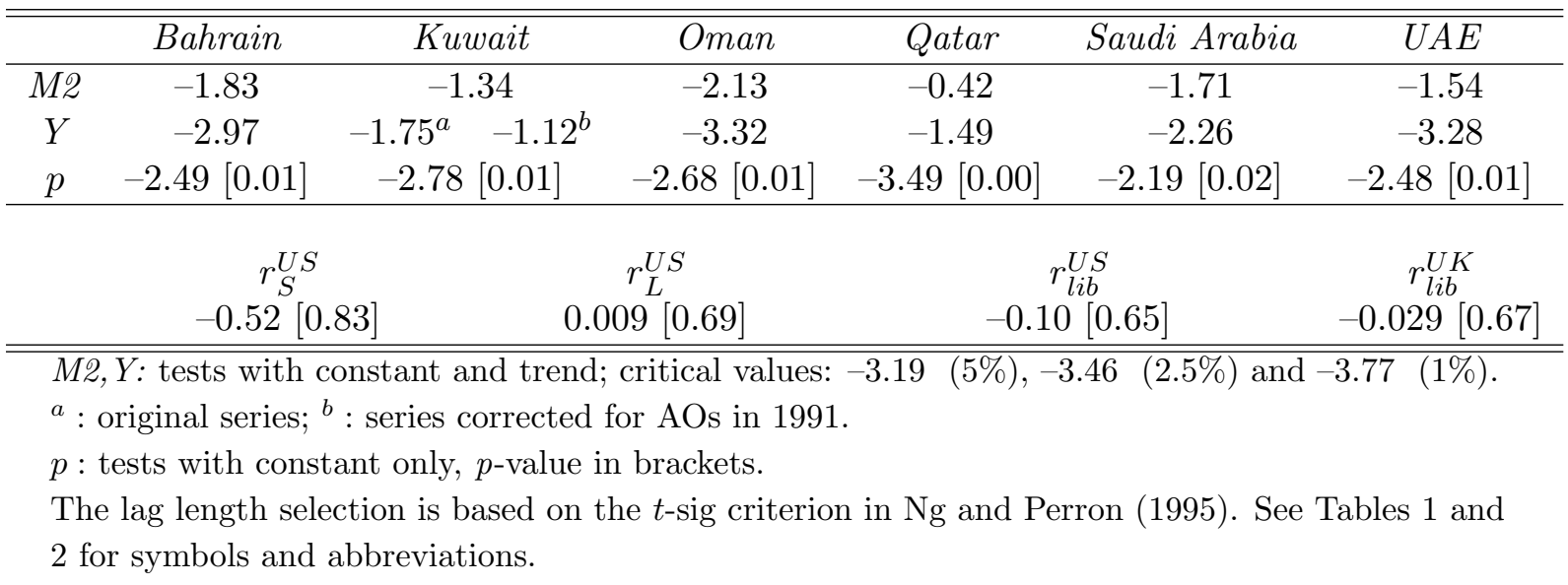

clearly reject the null hypothesis of no cointegration for Bahrain, Oman and Saudi Arabia ( $p$ values are all smaller than 0.05), while they are large or even very large for Kuwait, Qatar and the UAE ( $p$-values equal to $0.17,0.19$ and 0.41 , respectively). In Saudi Arabia and the UAE, total GDP replaces non-oil GDP as a scale variable. ${ }^{13}$ At first, this finding may be surprising and it would appear to contradict the structural characteristics of these economies, where, up to now, crude oil production has not been economically integrated with the rest of the economy due to its high capital/labor ratio in all of its production stages. However, it is possible that the increasing expansion of domestic absorptive capacity (relative to the large external rent collected from oil) of these economies has allowed them to siphon off a greater fraction of oil revenues as a constituent part of the domestic income-expenditure stream. As such, Saudi Arabia and the UAE, respectively, are the largest and second-largest economies in the GCC region. Furthermore, the fact that a large portion of Saudi Arabia's oil revenues is held as reserves with its central bank (rather than taking the form of foreign assets) suggests that aggregate income has turned out to be a vital concept for the purposes of explaining the behavior of the money demand by domestic economic agents. On the other hand, in the early part of the sample the level of the UAE's non-oil GDP was much lower than M2 money and thus grew at a more rapid pace during the 1980s and 1990s, showing a bowed (concave-down) shape (cf. Fig. 5). During 2000-2009, the pace of money growth was higher while both non-oil output and total output grew at a similar pace (cf. Table 1). Examining Fig. 5 suggests that

\footnotetext{
${ }^{13}$ The GDP is clearly non-stationary in both countries, even allowing for a trend under the alternative hypothesis: the ADF-GLS is equal to -2.49 and -1.78 respectively in Saudi Arabia and the UAE, compared with a 0.10 critical value of -2.89 .
} 
M2 looks more compatible with total GDP, which may explain why they are cointegrated in the Granger sense.

Table 4: Engle-Granger no-cointegration tests

\begin{tabular}{cccccc}
\hline \hline Bahrain $^{a}$ & Kuwait $^{a}$ & Oman $^{a}$ & Qatar $^{b}$ & Saudi Arabia $^{b}$ & UAE $^{b}$ \\
\hline-4.31 & -3.19 & -4.47 & -3.14 & -4.49 & -2.63 \\
$(0.03)$ & $(0.17)$ & $(0.006)$ & $(0.19)$ & $(0.01)$ & $(0.41)$ \\
\hline \hline
\end{tabular}

${ }^{a}$ : Model $(1) ;{ }^{b}$ : Model (2).

MacKinnon (1996) $p$-values in brackets.

In interpreting these results, we should not forget that, as stressed at the outset, they are obtained from a very small sample, so that non-rejections-of the null hypothesis could simply be the consequence of inadequate power. Enhanced power can be obtained from panel cointegration tests, provided they are chosen with care, as very strong cross-section dependence is clearly present in our dataset: even when abstracted from plausible common trends in GDP, the opportunity cost is measured in four countries by the same interest rate (i.e., the US Treasury bill rate). We thus have an observable non-stationary factor common to a subset of the units of the panel. Fortunately, the bootstrap tests developed by Di Iorio and Fachin (2011), which enjoy good size and power properties even in strongly dependent panels, provide an adequate answer to this need. If we exploit this procedure, the null hypothesis of no cointegration in the panel sense can be tested through three different summary statistics of the individual tests: mean, median and maximum. The first two statistics test the null hypothesis of no cointegration in the panel as a whole, while the latter is the most suitable for the null hypothesis of no cointegration in all units. ${ }^{14}$ As it can be appreciated from Table 5, all $p$-values of the panel cointegration tests are smaller than 0.05 , including that for the maximum of the individual statistics. This implies that cointegration holds in all GCC countries; the failure to find a long-run equilibrium money demand function in some individual countries is merely due to low statistical power.

Having concluded in favor of the existence of a long-run equilibrium in all countries, we can proceed to estimate their coefficients. To this end, we apply the widely used Fully Modified Ordinary Least Squares (FMOLS) estimator. The coefficients (Table 6) are generally reasonable and not too dispersed, especially if we take estimation error into account, which is inevitably large in view of the small sample size. For instance, income elasticity ranges from 0.49 to 1.05,

\footnotetext{
${ }^{14}$ On the connection between panel test statistics and panel null hypothesis, see Chang and Nguyen (2012), and Pedroni (2004).
} 
Table 5: Panel cointegration tests

\begin{tabular}{lcc}
\hline \hline Mean & Median & Maximum \\
\hline-3.17 & -2.91 & -2.34 \\
$(0.02)$ & $(0.03)$ & $(0.01)$ \\
\hline In brackets: bootstrap $p$-values $\times 100$, \\
5000 bootstrap redrawings.
\end{tabular}

but the standard error of the lowest coefficient (the UAE) is 0.23. As M2 includes interestearning savings deposits, the relatively higher income elasticities in the three smaller GCC economies (i.e., Bahrain, Kuwait and Oman) may reflect a greater impact of income on savings deposits than does the income elasticity of alternative assets. Put differently, this portfolio aspect of money demand makes savings deposits a "superior good" for households who experience income increases during the sample period (Friedman and Schwartz, 1963). ${ }^{15}$ By comparison, the estimated income elasticity and interest elasticity of money demand in the remaining three countries (i.e., Qatar, Saudi Arabia and the UAE) - which utilize the log-log model implied by Equation (2) - are more closely in line with the prediction of the Baumol-Tobin model of the transactions demand for money which implies an income elasticity of +0.5 and an interest elasticity of -0.5 . The higher interest elasticity in the UAE compared with Saudi Arabia can be explained in the light of rapid income growth in the former compared with the latter. As incomes rise, more and more individuals tend to switch between (non-interest yielding) money and interest-bearing assets, helping the interest (income) elasticity of money demand to rise (fall). Considering the fact that a large portion of oil revenues is added to the foreign assets of Saudi Arabia's central bank (the Saudi Arabia Monetary Agency; SAMA), the high elasticity coefficient for the foreign interest rate may reflect the behavior of SAMA rather than the reaction of the Saudi population (Fadil, 1985). Since the transaction demand for money is only a component of the overall money demand, other motives for holding money as a consequence of maximizing behavior could entail the speculative motive and precautionary expenses.

We can learn more from Fig. 6, which shows the HP-filtered smoothed US 3-month Treasury bill and the log of income velocity of M2 money. To be consistent, we use non-oil GDP as the measure of income and an identical interest rate (in level) for all six countries. The results are not affected if total GDP is alternatively used for Saudi Arabia and the UAE. As Fig. 6

\footnotetext{
${ }^{15}$ Strictly speaking, an income elasticity in excess of unity is generally considered as real money balances being a luxury good.
} 
Table 6: GCC long-run money demand functions, 1980-2009: FMOLS estimates

\begin{tabular}{cccccccc}
\hline \hline & Bahrain & Kuwait & Oman & Qatar & Saudi Arabia & UAE & Mean \\
\hline \multirow{2}{*}{$Y$} & 1.05 & 0.86 & 0.97 & 0.86 & 0.61 & 0.49 & \multirow{2}{*}{0.81} \\
& $(0.08)$ & $(0.07)$ & $(0.08)$ & $(0.11)$ & $(0.25)$ & $(0.23)$ & \\
\hline \multirow{2}{*}{$r$} & -0.21 & -0.05 & -0.14 & -0.57 & -0.55 & -0.71 & \multirow{2}{*}{0.37} \\
\hline \hline
\end{tabular}

$Y$ : total GDP for Saudi Arabia and the UAE; other countries: non-oil GDP.

$r$ : Bahrain, Kuwait, Oman: $\left(r_{S}^{U S}\right)$; Qatar: $\log \left(r_{L}^{U S}\right)$; Saudi Arabia: $\log \left(r_{S}^{U S}\right)$; UAE: $\log \left(r_{l i b}^{U S}\right)$. Standard errors in brackets.

shows, except for Kuwait, M2 velocity declined over time in all countries during the sample period, which means that money grew more quickly than income (consistent with the statistics reported in Table 1). By itself, this fact suggests that the income elasticity of money is higher (or greater than unity), as is evident in the smaller GCC economies. The roughly trendless velocity in Kuwait can be attributed to its much lower money growth than the GCC average (see Table 1) and a very low interest semi-elasticity. Other factors that may contribute to the fairly stable velocity in Kuwait - except for the short-term movements during the 1990-91 Gulf War - are lower population growth and a fairly sophisticated financial sector compared to other GCC countries. ${ }^{16}$ The relatively high interest elasticity in Qatar, Saudi Arabia and the UAE reconciles the much higher velocity (in size) documented in these countries; whereas the falling velocity can be explained by the fall in interest rates over the study period. Overall, the declining velocity appears to be consistent with the transformation of the GCC from simple economies into complex, dynamic ones, which is generally linked with an increase in the monetization of the economy. ${ }^{17}$

The next step in our empirical analysis is to test the homogeneity (or poolability) of the long-run money demand parameters across countries. Should the poolability hypothesis turn out not to be rejected by the data, we could obtain considerably more reliable estimates, as the sample size would grow from $T=38$ to $T \times N=38 \times 6=208$, where $T$ represents the time period and $N$ represents the number of countries in the panel. Accounting for cross-section

\footnotetext{
${ }^{16}$ During the period of this study, population growth in Kuwait was lowest among the GCC countries. The Kuwaiti stock exchange is the first official bourse established in the GCC region and includes the largest number of listed companies. Furthermore, Kuwait has the largest number of investment companies proving asset/portfolio management services and, until very recently, was the only market with an active trade in derivative securities.

${ }^{17}$ In the development literature, this transformation is often referred to as the 'process of monetization.' Increases in the share of national output sold in organized markets, increases in the fraction of the population working for wages and increases in the number of intermediate payments required in production are the most frequently cited factors underlying a decline in velocity the early stage of economic growth. See Ireland (1994) for an additional discussion.
} 
dependence is again the key point of the statistical procedure. Recently, Di Iorio and Fachin (2012a) proposed a test based on the range of the coefficients across units. The null hypothesis of the homogeneity of the coefficients across units is expressed as the hypothesis that the range of the estimates across units is zero, and inference is carried out through the sieve bootstrap. The test seems to enjoy good size and power properties, but in our set-up, its implementation requires some care. The point is that the sieve bootstrap requires us to estimate a VAR with three variables (the cointegrating residuals and the two right-hand side variables). Given our small time sample size, the VAR estimates may be imprecise and the test might suffer from some power problems. We thus computed the test with both the standard formulation (sieve-VAR for short) and a parsimonious version, replacing the VAR with separate autoregressive (AR) models for the equation residuals and the two right-hand variables (sieve-AR for short); more details are provided in the Appendix.

Table 7: Range poolability test ( $p$-values)

\begin{tabular}{|c|c|c|c|c|c|c|}
\hline & & OLS & & & IOLS & \\
\hline & & & & & p & \\
\hline & Range & $V A R$ & $A R$ & Range & $V A R$ & $A R$ \\
\hline$Y$ & 0.48 & 1.00 & 0.97 & 0.54 & 0.96 & 0.93 \\
\hline$r$ & 1.05 & 1.00 & 0.36 & 0.93 & 1.00 & 0.47 \\
\hline
\end{tabular}

As expected, the $p$-values of the sieve-VAR test are larger than those of the sieve-AR test (see Table 7). However, for both variables and both estimators (OLS and FMOLS), they all overwhelmingly suggest no rejection of the poolability hypothesis, implying parameter homogeneity across the six Gulf countries. This finding is likely to be important for the Gulf Monetary Council, which is currently preparing the legal and institutional framework of the single currency, including an exchange rate system and setting up the (common) central bank.

Since our results suggest that the GCC-wide panel can, in fact, be pooled, the natural next step is to estimate the parameters of the pooled money demand function. The estimation of the pooled model may appear a trivial task. In fact, this is not the case. As already argued, strong short- and long-run cross-section dependence (CSD) is present in our dataset. Now, although various panel estimators of long-run relationship in dependent panels have been proposed, it is easily seen that, unfortunately, none of them is fully suitable for our small $N$, small $T$ dataset. 
Essentially, these estimators can be grouped in two classes: (i) SUR estimators (DSUR in Mark, Ogaki and Sul, 2005; FMSUR in Moon, 1999), which model the dependence by estimating the long-run covariance matrix of the system and (ii) estimators which model dependence as unobservable common factors entering the data generating process. These common factors may be estimated either through simple cross-section averages (leading to the CCE estimators of Pesaran (2006) and Kapetanios, Pesaran and Yamagata (2011)) or through factor methods (leading to the 2sFM of Bai and Kao (2006) and CupFM of Bai, Kao and Ng (2009)).

Let us examine the two classes of estimators in turn. SUR estimators have been shown by Di Iorio and Fachin (2012b) to perform poorly compared to their single-equation counterparts (DOLS and FMOLS) with sample sizes such as $T=50$, and $N=10$, and to be even unfeasible with smaller $T / N$ ratios. Essentially, SUR estimators are only feasible with large $T$ and small $N$. Considering that the estimation of the long-run covariance matrix of the system is a considerably more difficult task (Mark et al., 2005, describe it as "thorny") than that of the contemporaneous covariance matrix needed for the standard SUR, these difficulties are not too surprising. Conversely, obtaining reliable estimates of unobservable common factors clearly requires a large cross-section dimension, so that these estimators are feasible even for small $T$, provided $N$ is large. For instance, the simulations designs by Kapetanios et al. (2011) and Bai et al. (2009) allow for a value of $T$ as small as 20, but $N$ is always greater than 20. Summing up, estimators taking CSD into account require at least one of the two panel dimensions to be large; in our case, both are small. The expected poor performance of estimators allowing for CSD has been confirmed by exploratory analysis: we essentially obtained estimates with incorrect signs, very small parameter values and large variances.

We thus report and discuss only estimators which do not take CSD into account. To obtain a more reliable picture, we report the results delivered by four different estimators: the panel mean group (PMG) estimator of Pesaran, Smith and Shin (1999); panel DOLS (PDOLS), both the within version of Kao and Chiang (2000) and the between or group mean version of Pedroni (2001); and the pooled FMOLS (PFMOLS) estimator of Pedroni (2000). The results are reported in Table 8. To assess the estimates, we can take the average of the heterogenous estimates or mean group estimate ${ }^{18}$ as a reference, which, under no CSD, converges at the rate $T \sqrt{N}$ to the true mean of the elasticities (see e.g., Pesaran, Smith and Im, 1995). The various pooled estimates of the GDP elasticity, ranging from 0.81 (Kao and Chang's PDOLS)

\footnotetext{
${ }^{18}$ Based on the average of the country estimates reported in Table 6.
} 
to 1.21 (PFMOLS), are generally larger than the group mean estimate (0.81). The opposite holds for those of the interest rate elasticity, which can be taken to fall within the range -0.17 (Pedroni's PDOLS) and -0.10 (PMG; Kao and Chang's PDOLS produces 0.005, but this is not significant), while the average of the individual FMOLS estimates is -0.37 . Keeping in mind that the pooled estimates must be taken with some caution, we may conclude that, essentially, the income elasticity seems to be rather precisely identified, while the interest rate elasticity seems to be more difficult to evaluate.

Table 8: GCC long-run money demand functions, 1980-2009

\begin{tabular}{ccccc}
\hline \hline & PMG & PDOLS $^{a}$ & PDOLS $^{b}$ & PFMOLS \\
\hline$Y$ & 1.16 & 0.81 & 1.17 & 1.21 \\
& $(0.16)$ & $(0.08)$ & $(0.06)$ & $(0.05)$ \\
$r$ & -0.097 & 0.005 & -0.17 & -0.13 \\
& $(0.08)$ & $(0.01)$ & $(0.10)$ & $(0.05)$ \\
\hline \hline
\end{tabular}

${ }^{a}$ : Kao and Chiang $(2000){ }^{b}$ : Pedroni (2001). All variables as in Table 6; standard errors are given in brackets.

We conclude our empirical analysis by relating our results to existing panel studies, especially those examining long-run demand for M2 money. Table 9 presents summary of findings of selected panel studies. A direct comparison between our results (Table 8) and those reported in Table 9 is problematic because of - among other factors - the sensitivity to the choice of sample period, because of the exact functional form and number of lags, and because of the inclusion and precise definition of the interest rate variable. However, we can nonetheless reconcile the differences in the size of the income and interest elasticities of money demand in terms of the non-standard nature of the GCC economies compared to other regional economies. For instance, the comparatively low income elasticity of M2 in the GCC region tends to capture the lack of availability of interest-earning assets in the banking system. It also reflects the unique nature of GCC's labor market, which is dominated by expatriate workers who tend to hold demand deposits for meeting most of their transactions needs, while remitting a sizable portion of their wage income to families in their country of origin. Although our results show that in the GCC, the interest elasticity of money demand is definitely negative and significant, and is comparable to other regional estimates, we should not forget that this results depend on the use of US rates as proxies of country rates. 
Table 9: Overview of panel studies on M2 money demand

\begin{tabular}{llll}
\hline \hline Study & Countries & $\begin{array}{l}\text { Income } \\
\text { elasticity }\end{array}$ & $\begin{array}{l}\text { Interest rate } \\
\text { (semi-)elasticity }\end{array}$ \\
\hline Dreger et al. $(2007)$ & 10 EU countries & 1.73 to 1.94 & -0.09 to -0.06 \\
Hamori (2008) & 35 Sub-Saharan African countries & 1.00 to 1.02 & -0.28 to -0.01 \\
Hamori and Hamori (2008) & 11 EU countries & 1.50 to 1.59 & -0.16 to -0.05 \\
Valadkhani (2008) & 6 Asia Pacific countries & 1.48 & -0.03 to -0.02 \\
Fidrmuc (2009) & 6 CEEC countries & 0.23 to 1.06 & -0.009 to -0.002 \\
Narayan et al. $(2009)$ & 5 South Asian countries & 1.23 to 1.31 & -0.23 to -0.20 \\
\hline \hline
\end{tabular}

\section{Concluding Remarks}

In this work, we have studied the demand for broad money in the GCC area as well as its six member countries. The relevance of this monetary aggregate lies in the fact that it appropriately represents the domestic private liquidity of the GCC countries. Obtaining precise estimates of money demand is crucial for the central banks of the GCC region since, to a large extent, money supply is endogenously determined. Hence, knowing the income elasticity of long-run money demand, for example, helps central banks in determining the rate of monetary expansion that is consistent with long-run price level stability. We also examined the statistical admissibility of pooling single-country long-run money demand relationships at the GCC-wide level to shed light on the upcoming establishment of the GCC monetary union.

Given the small time sample size available, we supplemented individual time series modeling with panel cointegration tests. The individual and panel analysis led us to conclude that there is evidence of the long-run equilibrium relationship for money demand - both nationally and regionally.

The estimated income and interest elasticities of money demand in Qatar, Saudi Arabia and the UAE - which are obtained using the log-log specification of money demand - appear to satisfy the prediction of the Baumol-Tobin version of the inventory analysis of the transactions demand for money. By comparison, using the conventional semi-log specification of money demand, income elasticities in the other GCC economies reflect portfolio demand more strongly than transaction demand with a generally lower interest rate (semi-)elasticities. We discuss how the movements in income velocity can reconcile the varying elasticities documented across the six countries. Finally, the range poolability test suggests that the null hypothesis of parameter homogeneity cannot be rejected. The pooled estimates of the regional money demand yield 
an income (interest) elasticity parameter of 0.81 to 1.21 ( -0.17 to -0.10 , with a further nonsignificant positive estimate of 0.005 ), depending on the pooled estimator used.

It is always a daunting task to satisfy the theoretical properties of time series methods in empirical analysis with serious data limitations. Although the short time span and problematic data used in this paper may make it difficult to interpret the estimation results meaningfully, we have tried to circumvent the problems by correcting for influential observations as well as by employing recently developed econometric tests that maintain reasonably good size and power in a small panel. Given the paucity of sound empirical analysis of long-run money demand function for the GCC area, we hope that the results presented here will be a source of benefit for relevant policy formulation. 


\section{A A bootstrap range poolability test}

For the sake of simplicity, assume the bivariate cointegrating model:

$$
y_{i t}=\theta_{i}+\beta_{i} x_{i t}+\epsilon_{i t}
$$

The null hypothesis of coefficient homogeneity, $H_{0}: \beta_{i}=\beta \forall i$, can be expressed as $H_{0}: R=0$, where $R=\operatorname{Max}_{i \in[1, N]}\left(\beta_{i}\right)-\operatorname{Min}_{i \in[1, N]}\left(\beta_{i}\right)$. A parsimonious sieve bootstrap algorithm suitable for testing this hypothesis, adapted from Di Iorio and Fachin (2012a), is the following:

1. Estimate (3) by any consistent procedure, obtaining the residuals $\left\{\widehat{\epsilon}_{i t}\right\}_{t=1}^{T}$ for each unit $i$.

2. Compute the range of the $N$ coefficients; to avoid scale effects, it is advisable to use a normalized version: $\widehat{R}_{j N}=\left[\operatorname{Max}_{i \in[1, N]}\left(\widehat{\beta}_{j i}\right)-\operatorname{Min}_{i \in[1, N]}\left(\widehat{\beta}_{j i}\right)\right] / \operatorname{Max}_{i \in[1, N]}\left|\widehat{\beta}_{j i}\right|$.

3. Fit AR models of order $p_{i}$ to each of the $N$ time series of the cointegrating residuals $\left\{\widehat{\epsilon}_{i t}\right\}_{t=2}^{T}$ and the differences of the right-hand variable, $\left\{\Delta x_{i t}\right\}_{t=2}^{T}: \widehat{\epsilon}_{i t}=\sum_{j=1}^{p_{\epsilon i}} \phi_{\epsilon j} \widehat{\epsilon}_{i t-j}+\nu_{\epsilon i t}$, $\Delta x_{i t}=\sum_{j=1}^{p_{x i}} \phi_{x j} \Delta x_{i t-j}+\nu_{x i t}$.

4. Store the (empirically white noise) residuals $\left\{\widehat{\nu}_{x i t}\right\}_{t=p_{x i}+1}^{T}\left\{\widehat{\nu}_{\epsilon i t}\right\}_{t=p_{\epsilon i}+1}^{T}, i=1, \ldots, N$.

5. Letting $p_{M}=\max \left(p_{i}\right)$, resample with replacement the rows of the $\left(T-p_{M}\right) \times 2 N$ matrix $\mathbf{V}=\left[\widehat{\nu}_{x 1} \ldots \widehat{\nu}_{x N} \widehat{\nu}_{\epsilon 1} \ldots \widehat{\nu}_{\epsilon N}\right]$, where $\widehat{\nu}_{x i}=\left[\widehat{\nu}_{x i p_{M}+1} \ldots \widehat{\nu}_{x i T}\right]^{\prime}, \widehat{\nu}_{\epsilon i}=\left[\widehat{\nu}_{\epsilon i p_{M}+1} \ldots \widehat{\nu}_{\epsilon i T}\right]^{\prime}$, obtaining a matrix of pseudo-residuals $\mathbf{V}^{*}=\left[\widehat{\nu}_{x 1}^{*} \ldots \widehat{\nu}_{x N}^{*} \widehat{\nu}_{\epsilon 1}^{*} \ldots \widehat{\nu}_{\epsilon N}^{*}\right]$. Since entire rows swap places with the columns fixed, the cross-unit dependence structure of the matrix $\mathbf{V}$ is preserved.

6. Recursively construct the pseudo-series $\epsilon_{i t}^{*}=\sum_{j=1}^{p_{\epsilon i}} \widehat{\phi}_{\epsilon j} \epsilon_{i t-j}^{*}+\nu_{\epsilon i t}^{*}, \Delta x_{i t}^{*}=\sum_{j=1}^{p_{i}} \widehat{\phi}_{x j} \Delta x_{i}^{*}+$ $\nu_{x i t}^{*}$, setting the initial $p_{M}$ values equal to the observed values $\left(\Delta x_{i t}^{*}=\Delta x_{i t}, \epsilon_{i t}^{*}=\right.$ $\left.\widehat{\epsilon}_{i t}, t=1, \ldots, p_{M}\right)$.

7. Cumulatively sum the values of $\Delta x^{* \prime}$ to obtain the values of $x^{* \prime}$.

8. Compute pseudodata obeying the null hypothesis of slope homogeneity: $y_{i t}^{*}=\widehat{\theta}_{i}+\beta^{0} x_{i t}^{*}+\epsilon_{i t}^{*}$, $i=1, \ldots, N, t=1, \ldots, T$.

9. Estimate the cointegrating regression (3) on the dataset $\left\{y_{t}^{*}, x_{t}^{*}\right\}$, obtaining estimates of the cointegrating coefficients $\beta_{i}^{*}, i=1, \ldots, N$.

10. Compute the range of the bootstrap estimates: $R_{N}^{*}=\left[\operatorname{Max}_{i \in[1, N]}\left(\beta_{i}^{*}\right)-\operatorname{Min}_{i \in[1, N]}\left(\beta_{i}^{*}\right)\right] / \operatorname{Max}_{i \in[1, N]}\left|\beta_{i}^{*}\right|$.

11. Repeat $4-10 B$ times, storing the $B$ ranges.

12. Compute the bootstrap $p$-value as the right tail of the distribution of the $R_{N}^{* \prime} s: p^{*}=\operatorname{prop}\left(\mathbf{R}_{N}^{*}>\widehat{R}_{N}\right)$, where $\mathbf{R}_{N}^{*}=\left[R_{N 1}^{*} \ldots R_{N B}^{*}\right]$. 
Figure 1: Real M2 growth in GCC countries, 1980-2009 (log difference)

(a) Bahrain

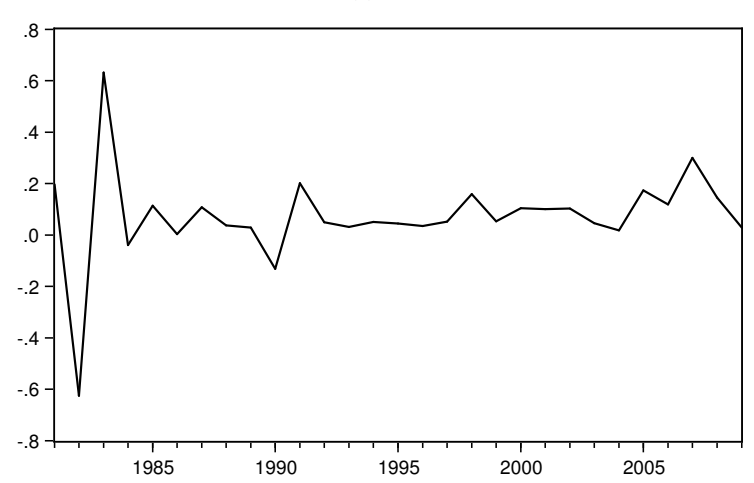

(c) Oman

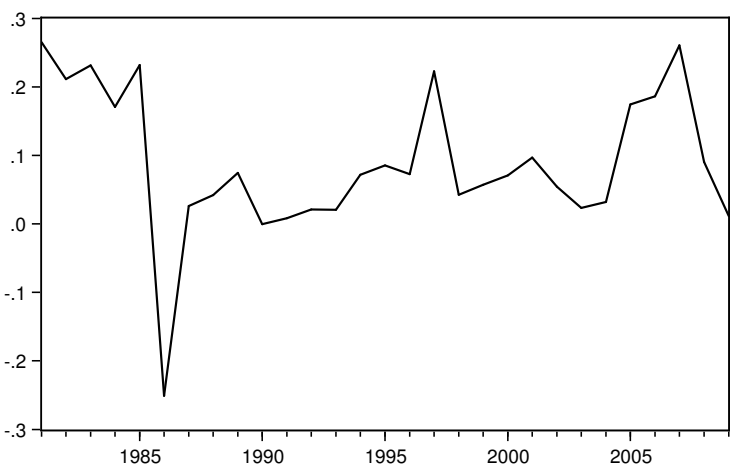

(e) Saudi Arabia

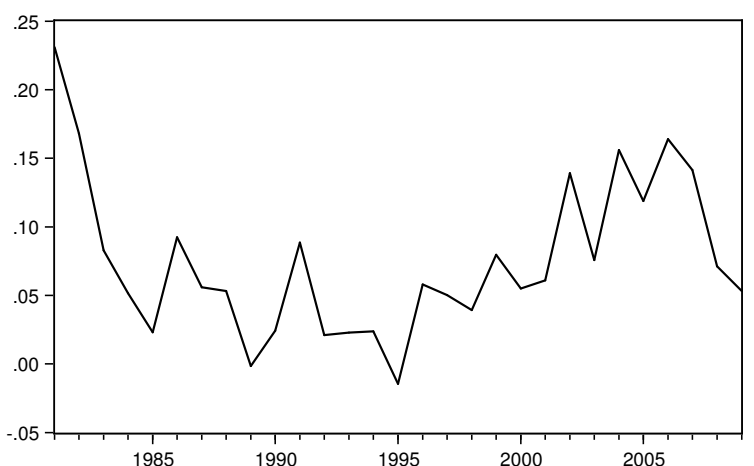

(b) Kuwait

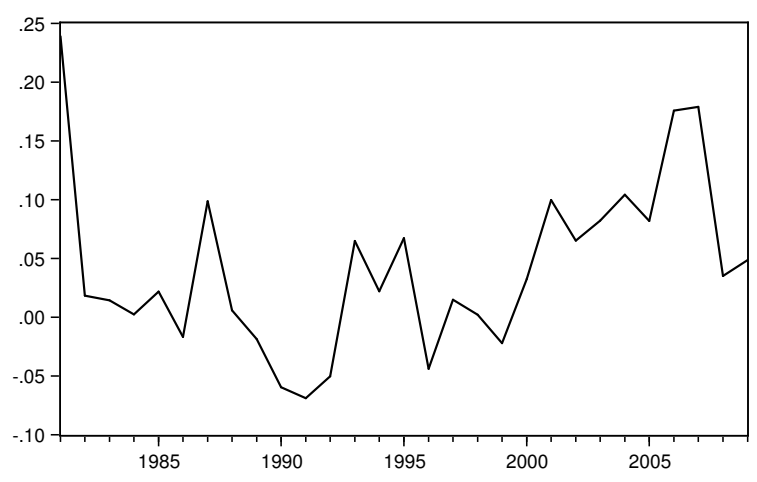

(d) Qatar

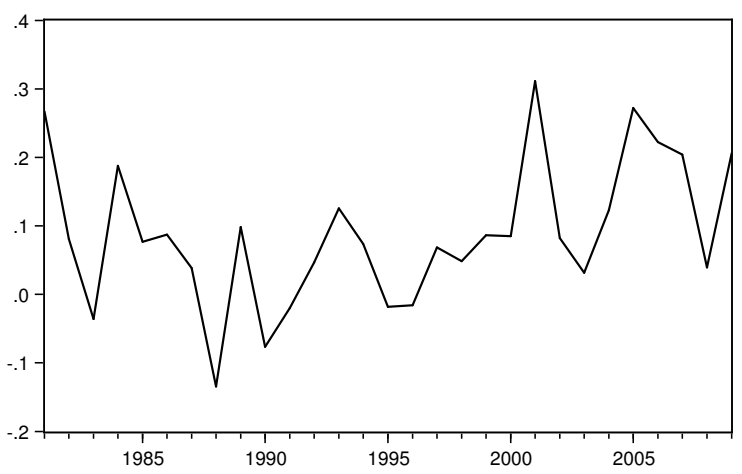

(f) United Arab Emirates

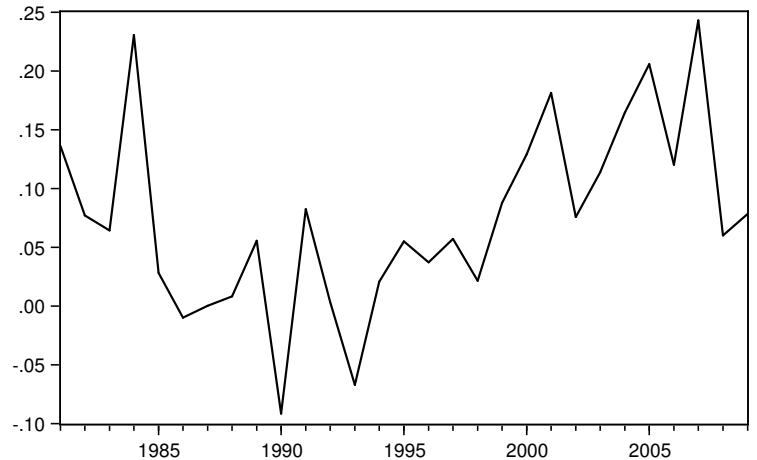

Source: International Financial Statistics, International Monetary Fund; World Development Indicator, World Bank. 
Figure 2: Total real GDP and non-oil real GDP growth in GCC countries, 1980-2009 (log difference)

(a) Bahrain

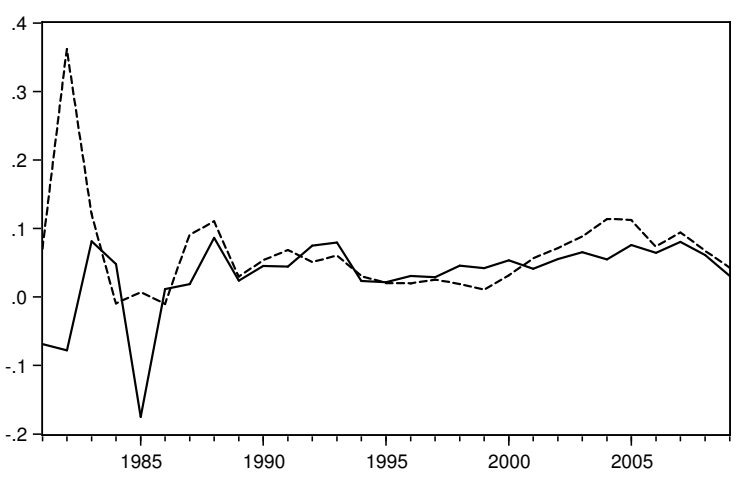

(c) Oman

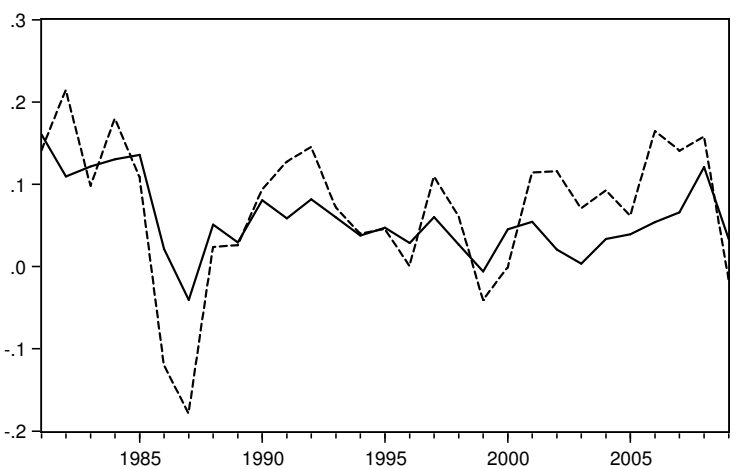

(c) Saudi Arabia

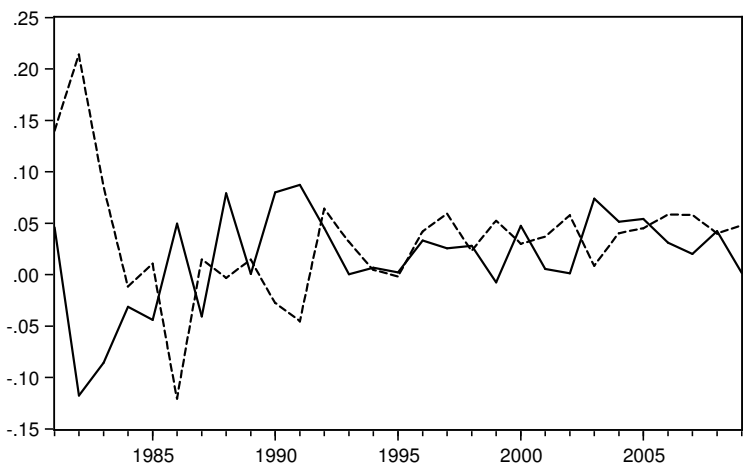

(b) Kuwait

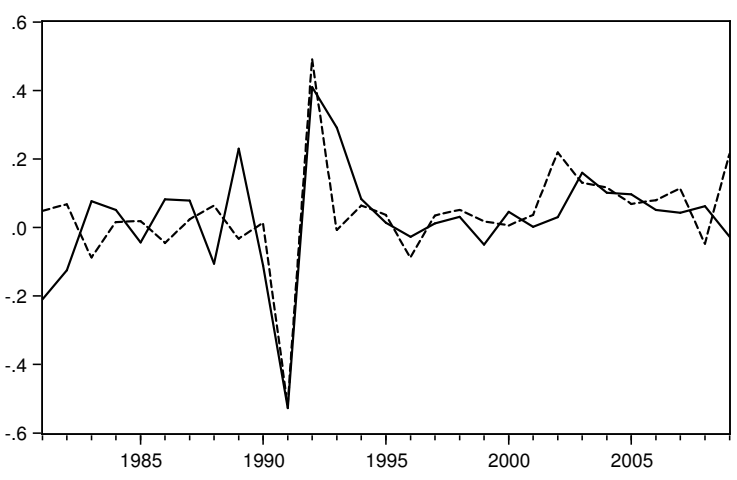

(d) Qatar

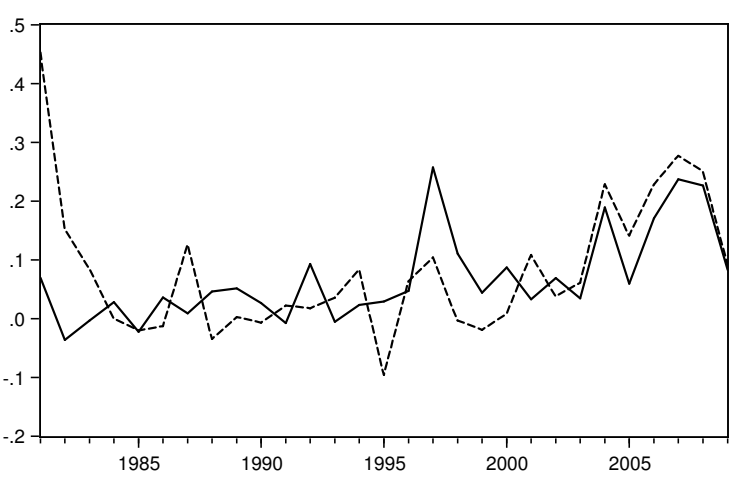

(f) United Arab Emirates

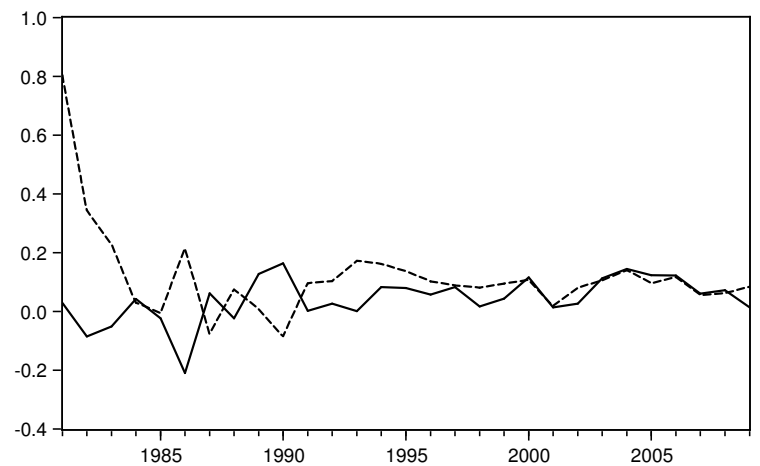

Total real GDP (solid line), non-oil real GDP (dashed line).

Source: National Accounts Main Aggregate Database, United Nations. 
Figure 3: International interest rates, 1980-2009 (percent).

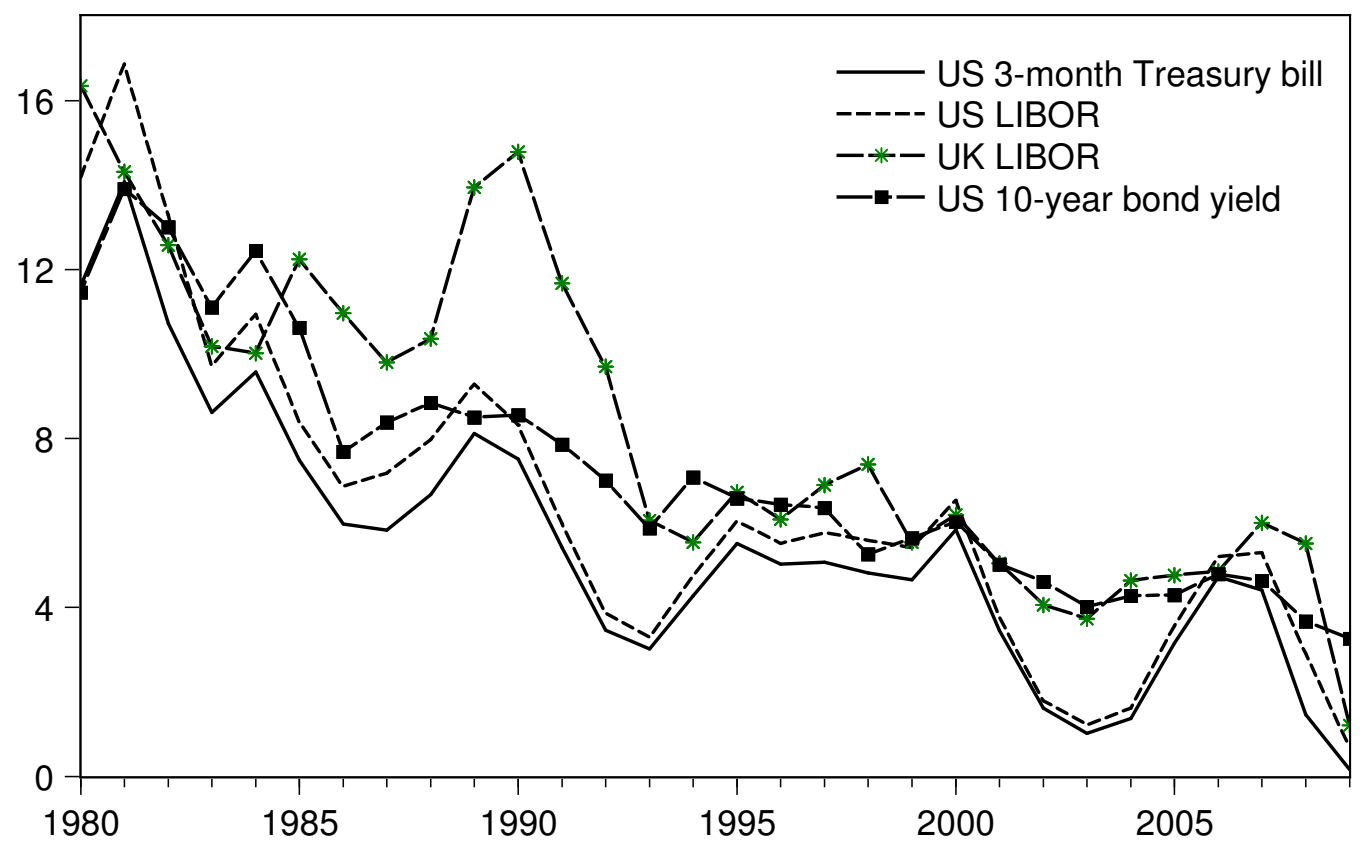

Source: International Financial Statistics, International Monetary Fund. 
Figure 4: Inflation rates in GCC countries, 1980-2009 (percent).
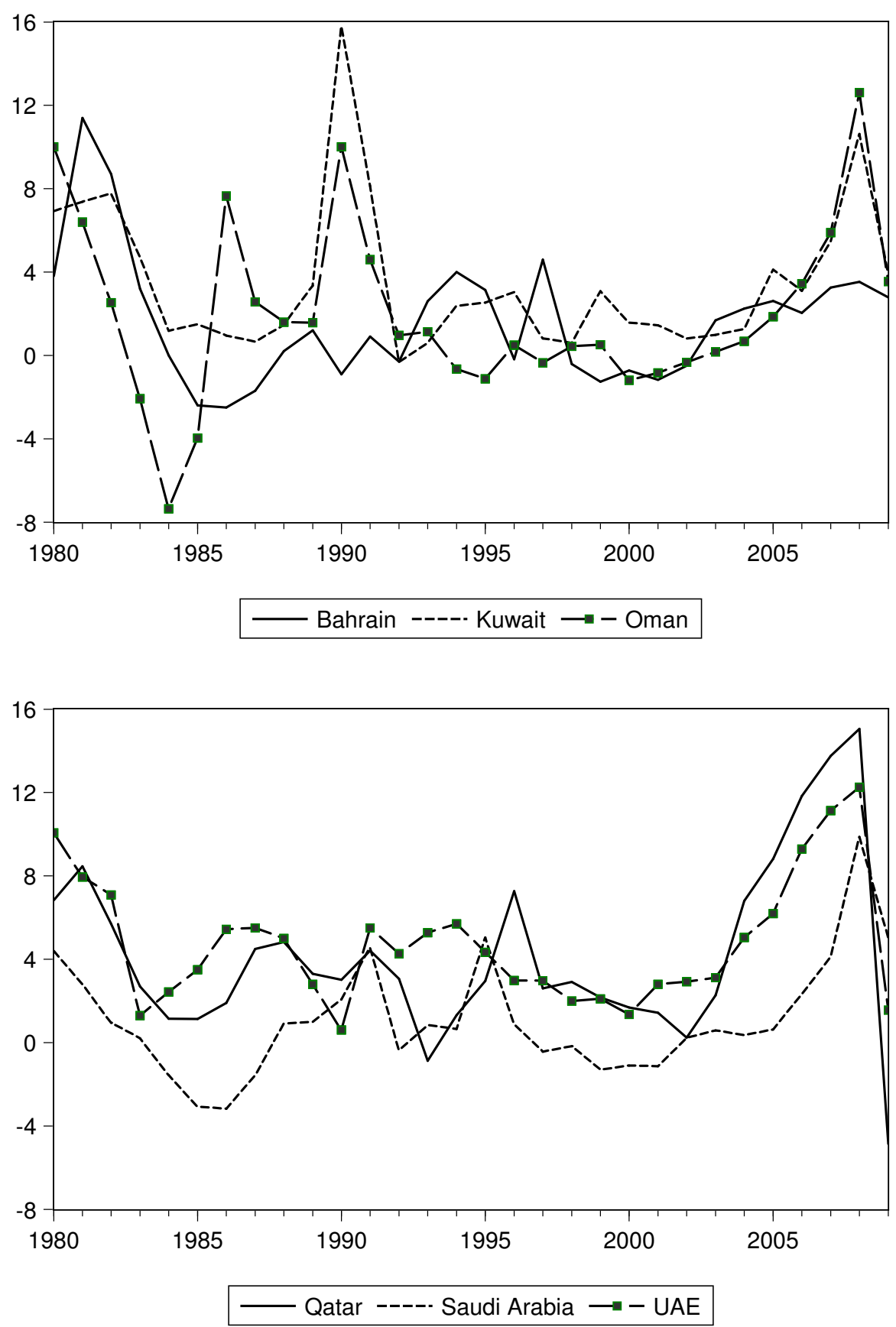

Average consumer prices. Source: World Economic Outlook, International Monetary Fund. 
Figure 5: M2 money, non-oil GDP and total GDP in the UAE, 1980-2009.

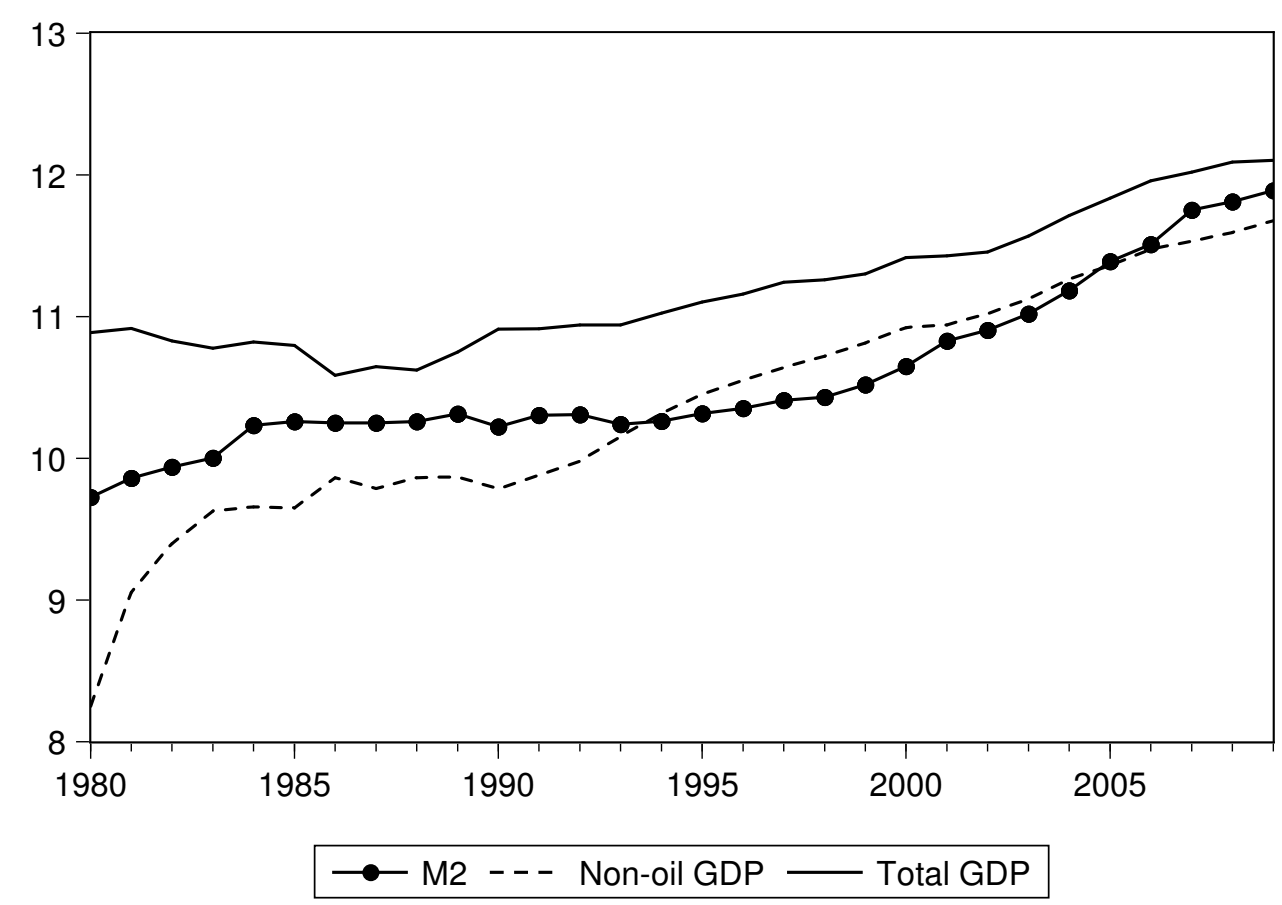

Logarithm, real values. Sources: International Financial Statistics, International Monetary Fund; National Accounts Main Aggregate Database, United Nations. 
Figure 6: Velocity and the interest rate, 1980-2009.
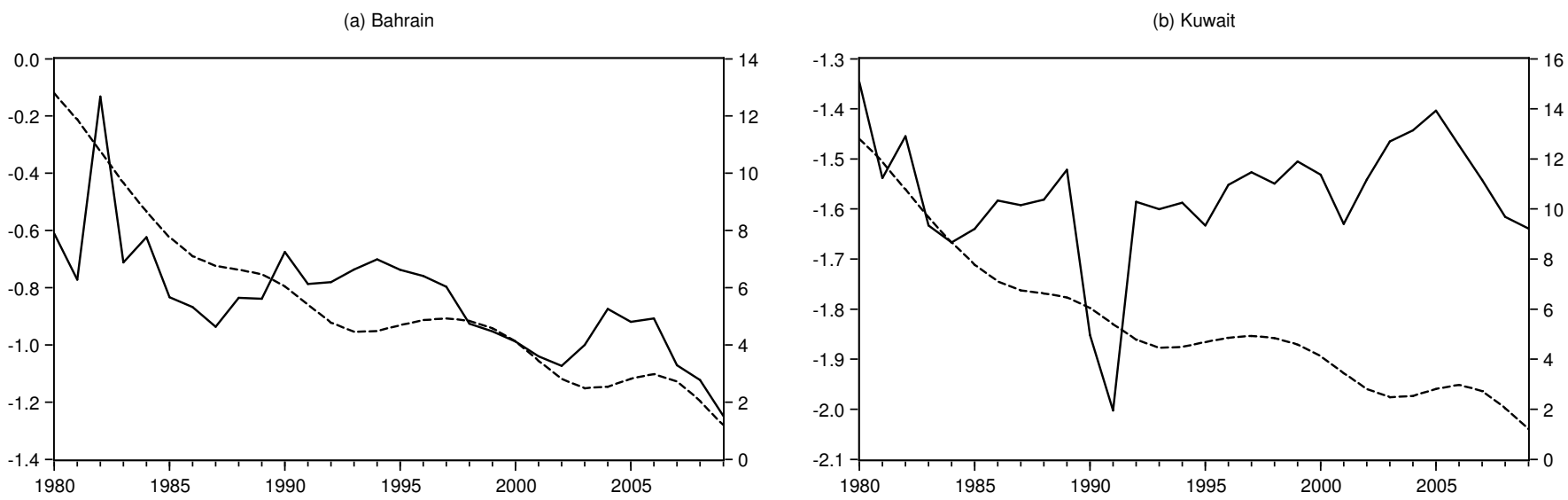

(c) Oman
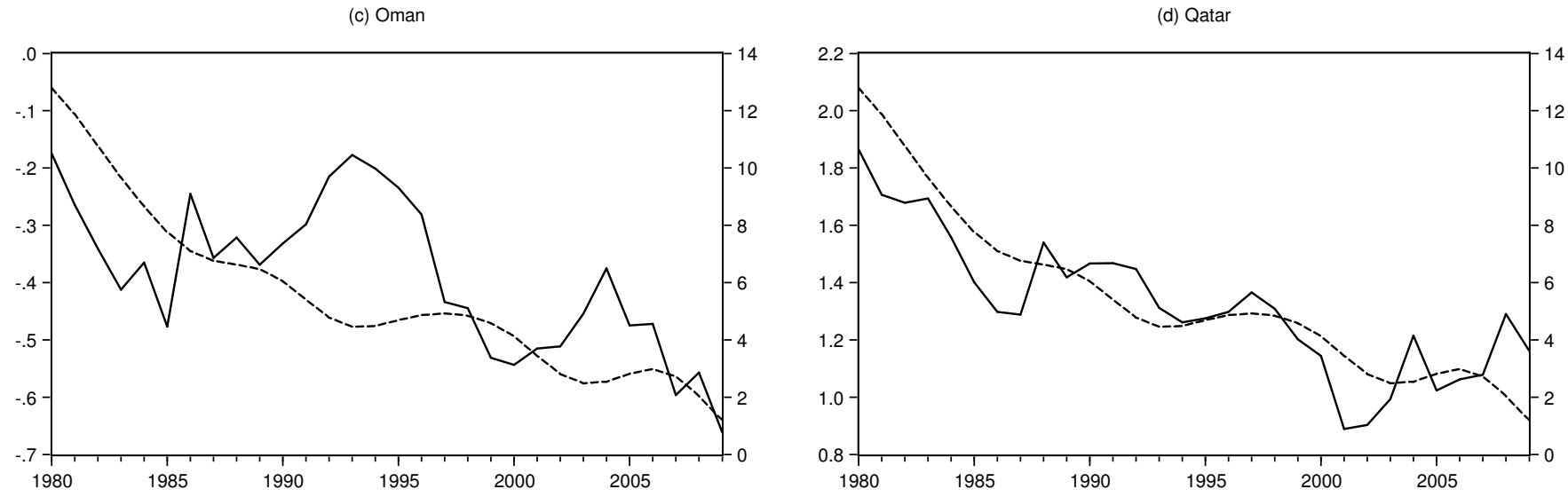

(e) Saudi Arabia

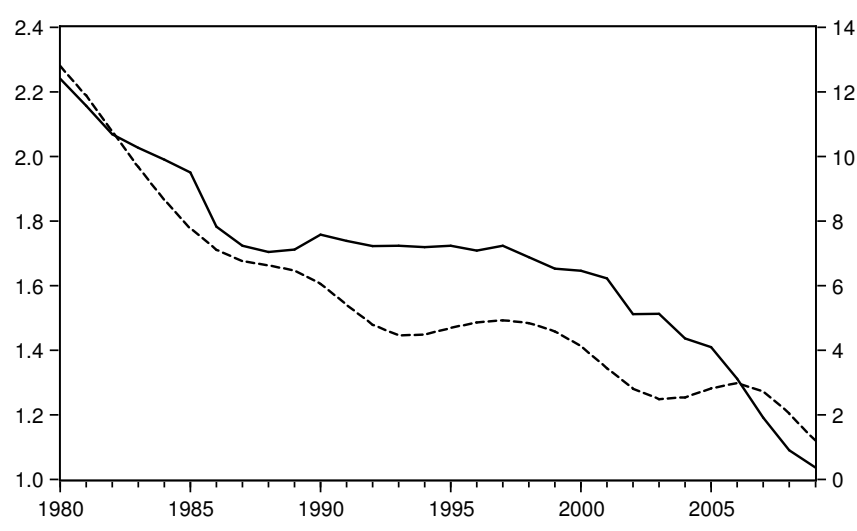

(f) United Arab Emirates

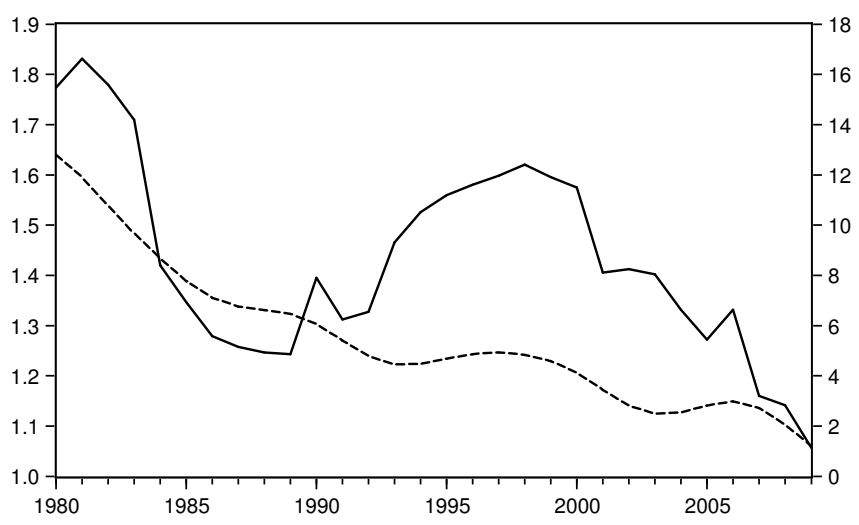

Note: Logarithm of income velocity (solid line, left axis); HP-filtered US 3-month Treasury bill (dashed line, right axis). The income velocity is computed using non-oil GDP as the scale variable and M2 money as the monetary aggregate. 


\section{References}

AlKholifey, A. and Alreshan, A. (2010). GCC monetary union. IFC Bulletin No. 32, Bank of International Settlements, 17-51.

Bai, J. and Kao, C. (2006). On the estimation and inference of a panel cointegration model with cross-sectional dependence. In Baltagi, B. (Ed.) Contributions to Economic Analysis. Elsevier, Amsterdam. pp. 3-30.

Bai, J., Kao, C. and Ng, S. (2009). Panel cointegration with global stochastic trends. Journal of Econometrics 149, 82-99.

Basher, S.A. and Elsamadisy, E.M. (2012). Country heterogeneity and long-run determinants of inflation in the Gulf Arab States. OPEC Energy Review 36, 170-203.

Baumol, W.J. (1952). The transactions demand for cash: An inventory theoretic approach. Quarterly Journal of Economics 66, 545-556.

Bova, E. (forthcoming). Interest Rate Spread in the GCC: The Role of Monetary Policy Intervention. IMF working paper. International Monetary Fund, Washington DC.

Buiter, W.M. (2008). Economic, Political, and Institutional Prerequisites for Monetary Union Among the Members of the Gulf Cooperation Council. CEPR discussion paper no. 6639. Centre for Economic Policy Research, London.

Chang, Y. and Nguyen C.M. (2012). Residual based tests for cointegration in dependent panels. Journal of Econometrics 167, 501-520.

Crockett, A.D. and Evans, O.J. (1980). Demand for money in Middle Eastern countries. IMF Staff Papers 27, 543-577.

Darrat, A.F. (1986). The demand for money in some major OPEC members: Regression estimates and stability result. Applied Economics 18, 127-142.

Darrat, A.F. and Al-Sowaidi, S.S. (2009). Financial progress and the stability of long-run money demand: Implications for the conduct of monetary policy in emerging economies. Review of Financial Economics 18, 124-131.

Di Iorio, F. and S. Fachin (2011). A Panel Cointegration Study of the Long-Run Relationship between Savings and Investments in the OECD Economies, 1970-2007. Working paper no. 3/2011, Department of the Treasury, Ministry of Economy and Finance, Roma.

Di Iorio, F. and S. Fachin (2012a). A simple sieve bootstrap range test for poolability in dependent cointegrated panels. Economics Letters 116, 154-156.

Di Iorio, F. and Fachin S. (2012b). A note on the estimation of long-run relationships in panel equations with cross-section linkages. Economics: The Open-Access, Open-Assessment E-Journal, Vol. 6, 2012-20. http://dx.doi.org/10.5018/economics-ejournal.ja.2012-20

Dreger, C., Reimers, H. and Roffia, B. (2007). Long-run money demand in the new EU member states with exchange rate effects. Eastern European Economics 45, 75-94.

Elliott, G., Rothenberg, T.J., and Stock, J.H. (1996). Efficient tests for an autoregressive unit root. Econometrica 64, 813-836.

Elsamadisy, E.M., Alkhater, K.R. and Basher, S.A. (2012). Pre- versus Post-Crisis Central Banking in Qatar. Working paper, Department of Research \& Monetary Policy, Qatar Central Bank, Doha. 
Espinoza, R. and Prasad, A. (2012). Monetary Policy Transmission in the GCC Countries. IMF working paper no. 12/132. International Monetary Fund, Washington, DC.

Fadil, F. (1985). Money demand in Saudi Arabia: An exchange of views: GNP as a variable for the demand for money in small oil economies: A comment. Journal of Economic Studies $5,62-64$.

Fidrmuc, J. (2009). Money demand and disinflation in selected CEECs during the accession to the EU. Applied Economics 41, 1259-1267.

Franses, P.H. and Haldrup, N. (1994). The effects of additive outliers on tests for unit roots and cointegration. Journal of Business $\&$ Economic Statistics 12, 471-478.

Friedman, M. and Schwartz, A.J. (1963). A Monetary History of the United States, 1867-1960. Princeton University Press, Princeton

Goldfeld, S.M. and Sichel, D.E. (1990). The demand for money. In Friedman, B. and Hahn, F. (eds), Handbook of Monetary Economics, vol. I, pp. 299-356. North-Holland, Amsterdam.

Gómez, V. and Maravall, A. (2001). Automatic modeling methods for univariate series, Ch.7 in Peña D., Tiao G.C. and Tsay, R.S. (eds.), A Course in Time Series Analysis. John Wiley and Sons, New York.

Hamori, S. (2008). Empirical analysis of the money demand function in Sub-Saharan Africa. Economics Bulletin 15, 1-15.

Hamori, S. and Hamori, N. (2008). Demand for money in the Euro area. Economic Systems $32,274-284$.

Harb, N. (2004). Money demand function: A heterogenous panel application. Applied Economics Letters 11, 551-555.

Hutchison, M.M. (1991). Aggregate demand, uncertainty and oil prices: The 1990 oil shock in comparative perspective. BIS Economic Papers no. 31. Bank of International Settlements, Basel.

International Monetary Fund (IMF, 2009). Global Financial Stability Report. October update. Washington, DC.

Ireland, P. (1994). Economic growth, financial evolution, and the long-run behavior of velocity. Journal of Economic Dynamics and Control 18, 815-848.

Kao, C. and Chiang, M.-H. (2000). On the estimation and inference of a cointegrated regression in panel data, in Baltagi, B. (Ed.) Nonstationary Panels, Panel Cointegration, and Dynamic Panels, Advances in Econometrics, Vol. 15, JAI Press, Amsterdam, pp. $161-178$.

Khan, M.S. (2009). The GCC Monetary Union: Choice of Exchange Rate Regime. Working Paper no. 09-1. Peterson Institute for International Economics, Washington, DC.

Kapetanios, G., Pesaran, M.H. and Yamagata, T. (2011). Panels with non-stationary multifactor error structures. Journal of Econometrics 160, 326-348

Lee, C-C., Chang, C-P. and Chen, P-F. (2008). Money demand function versus monetary integration: Revisiting panel cointegration among GCC countries. Mathematics and Computers in Simulation 79, 85-93. 
MacKinnon, J.G. (1996). Numerical distribution functions for unit root and cointegration tests. Journal of Applied Econometrics 11, 601-618.

Maravall, A. and Peña, D. (1992). Missing Observations and Additive Outliers in Time Series Models. Working paper 92/97, European University Institute, Department of Economics, Florence.

Mark, N., Ogaki, M. and Sul, D. (2005). Dynamic seemingly unrelated cointegrating regressions. Review of Economic Studies 72, 797-820.

Metz, H.C. ed. (1993). Persian Gulf States: A Country Study. GPO for the Library of Congress, Washington, DC. http://countrystudies.us/persian-gulf-states/.

Narayan, P., Narayan, S. and Mishra, V. (2009). Estimating money demand functions for South Asian countries. Empirical Economics 36, 685-696.

Ng, S. and Perron, P. (1995). ?Unit root tests in ARMA models with data dependent methods for the selection of the truncation lag. Journal of the American Statistical Association 90, $268-281$.

Pedroni, P. (2000). Fully modified OLS for heterogenous cointegrated panels. In Baltagi, B. (Ed.) Nonstationary Panels, Panel Cointegration, and Dynamic Panels, Advances in Econometrics, Vol. 15. JAI Press, Amsterdam. pp. 93-130.

Pedroni, P. (2001). Purchasing power parity tests in cointegrated panels. Review of Economics and Statistics 83, 727-731.

Pedroni, P. (2004). Panel cointegration, asymptotic and finite sample properties of pooled time series tests with an application to the PPP hypothesis. Econometric Theory 20, $597-625$.

Pesaran, M.H., Smith, R. and Im, K.S. (1995). Dynamic linear models for heterogenous panels. In Mátyás, L. and Sevestre, P. (Eds.) The Econometrics of Panel Data. Springer, Berlin.

Pesaran, M.H., Shin, Y. and Smith, R.P. (1999). Pooled mean group estimation of dynamic heterogeneous panels. Journal of the American Statistical Association 94, 621-624.

Pesaran, M.H. (2006). Estimation and inference in large heterogeneous panels with a multifactor error structure. Econometrica 74, 967-1012.

Rodríguez, G. and Rowe, N. (2007). Why U.S. money does not cause U.S. output, but does cause Hong Kong output. Journal of International Money and Finance 26, 1174-1186.

Sbeiti, W. and Haddad, A.E. (2011). Stock markets' dynamics in oil-dependent economies: Evidence from the GCC countries. International Research Journal of Applied Finance 2, 205-250.

Tahir, J. (1995). Recent Developments in Demand for Money Issues: Survey of Theory \& Evidence with Reference to Arab Countries. Working paper 9530, Economic Research Forum, Cairo.

Tas, B.K.O. and Togay, S. (2012). A direct test of the endogeneity of money: Implications for Gulf Cooperation Council (GCC) countries. Economic Modelling 29, 577-585.

Tobin, J. (1956). The interest elasticity of transactions demand for cash. Review of Economics and Statistics 38, 241-247. 
Valadkhani, A. (2008). Long- and short-run determinants of the demand for money in the Asian-Pacific Countries: An empirical panel investigation. Annals of Economics and Finance 9, 77-90.

Westerlund, J. and Basher, S.A. (2008). Mixed signals among tests for panel cointegration. Economic Modelling 25, 128-136.

Zaidi, I. (1990). Monetary coordination among the Gulf Cooperation Council countries. World Development 18, 759-768 